Check for updates

Cite this: RSC Adv., 2019, 9, 7400

Received 11th December 2018 Accepted 15th February 2019

DOI: 10.1039/c8ra10180a

rsc.li/rsc-advances

\section{Multisulfonate hyperbranched polyglycerol functionalized graphene oxide as an efficient reusable catalyst for green synthesis of benzo[a] pyrano-[2,3-c]phenazines under solvent-free conditions $\uparrow$}

\author{
Hossein Naeimi (D) * and Maryam Farahnak Zarabi \\ A novel acid catalyst was prepared based on growing hyperbranched polyglycerol (HPG) on the surface of \\ graphene oxide. Then, the hydroxyl groups of HPG on graphene oxide were functionalized by sulfonate \\ groups to form an acid catalyst. The catalyst displayed a good loading level of acidic groups on the \\ surface because of coating graphene oxide with HPG. This new catalyst is demonstrated to be highly \\ effective in the preparation of benzo[a]pyrano[2,3-c]phenazine dyes.
}

\section{Introduction}

Graphene, a flat monolayer of carbon atoms tightly packed into a two-dimensional (2D) honeycomb lattice, has been used in a wide range of applications such as electronic devices, solar cells, nano-catalysts, nanocomposites, molecular sensing, and chemical and biological sensors. ${ }^{\mathbf{1 - 8}}$ Graphene oxide (GO) is an oxidized form of graphene which is the most versatile and easily scalable. It is well-known that the presence of oxygen containing groups in GO including hydroxyl, epoxide and carbonyl groups provides reactive sites for chemical modification. ${ }^{9}$ The catalysts' activity strongly depended on the loading amount of their immobilized compounds. For these reasons, a rationalized choice for solving this problem in heterogeneous catalysts is immobilization of polymers on the solid surface. A class of hyperbranched polymers is polyglycerol with a tree-like structure and a large number of hydroxyl functional groups in its backbone and environs. ${ }^{10}$ The chemical grafting of HPG onto the surface of graphene oxide also supplies a suitable surface for their functionalization with organic compounds to obtain novel nanostructures. In this paper, we explored a novel catalyst based on multisulfonate hyperbranched polyglycerol modified graphene oxide (GO-HPG-SO $\left.\mathrm{S}_{3} \mathrm{H}\right)$. Graphene oxide possesses a large surface area which provides a good platform for grafting HPG. In addition, HPG can be readily grafted to the surface of graphene oxide by a one-step ring opening polymerization. Also, it is simple to alter the hydroxyl groups of HPG into sulfonate

Department of Organic Chemistry, Faculty of Chemistry, University of Kashan, Kashan, 87317, Islamic Republic of Iran. E-mail: naeimi@kashanu.ac.ir; Fax: +9803155912397; Tel: +98-03155912388

$\dagger$ Electronic supplementary information (ESI) available. See DOI: 10.1039/c8ra10180a groups, so the GO-HPG- $\mathrm{SO}_{3} \mathrm{H}$ can be scalably and costeffectively produced. ${ }^{11}$ It is expected that the GO-HPG- $\mathrm{SO}_{3} \mathrm{H}$ would show great performance as an acid catalyst because the HPG molecule has a hyperbranched structure and numerous sulfonate groups.

The natural occurrence of phenazine pigments has been known for a long time. Phenazine-based compounds are nitrogen-containing heterocycles that are the main core of many natural and synthetic organic materials ${ }^{12}$ and they are structural components of various kinds of bacteria species. ${ }^{13,14}$ These molecules are commonly employed in many fields such as antimalarial, ${ }^{15}$ trypanocidal, ${ }^{\mathbf{1 6}}$ fungicidal, ${ }^{17}$ antiplatelet, ${ }^{18}$ antitumor, and antiphrastic. ${ }^{15}$ In addition, fluorescent phenazine compounds are used as photo-sensitizers in photodynamic therapy (PDT). ${ }^{19}$ Also, chromenes have attracted great attention due to their widespread pharmaceuticals ${ }^{\mathbf{2 0 2} 21}$ properties such as antifungal $^{22,23}$ and antimicrobial activities. ${ }^{24}$ Although molecules with phenazines and chromenes moieties have attracted a lot of attention in drug discovery but functionalized benzo $[a]$ pyrano[2,3-c]phenazine derivatives have seldom been described.

In recent years, designs of multi-component reactions (MCRs) because of their advantages in comparison with multistep reactions according to environmental and economic considerations have received significant attention for the synthesis of biologically interesting compounds. A number of methods have been reported for the synthesis of benzo $[a]$ pyrano $[2,3-c]$ phenazine. The synthesis of benzo[a]pyrano[2,3-c]phenazine is carried out with various catalysts such as acetic acid, ${ }^{25}$ nano copper(II) oxide, ${ }^{26}$ ionic liquid, ${ }^{27}$ theophylline, ${ }^{28}$ and DABCO. ${ }^{12}$ Most of these catalysts have drawbacks, such as corrosive, non-reusable, and non-recoverable. 
Herein, we wish to describe a highly efficient method for the preparation of functionalized benzo[a]pyrano[2,3-c]phenazine derivatives via one-pot, two-step condensation reaction in the presence of GO-HPG-SO $\mathrm{S}_{3} \mathrm{H}$ as an efficient and reusable catalyst under solvent-free conditions.

\section{Results and discussion}

The process for the preparation of GO-HPG- $\mathrm{SO}_{3} \mathrm{H}$ catalyst is schematically described in Scheme 1. First, graphene oxide nanosheets were prepared using a modified Hummer's method.

There was a great amount of active hydrogen-containing functional groups including hydroxyl and carboxylic acid groups on graphene oxide nanosheets surface. Hyperbranched polymerization of glycidol was initiated by these active surface groups on graphene oxide nanosheets, producing a high hydrophilic PG layer on graphene oxide surface. ${ }^{29}$ In the next step, GO-HPG-SO ${ }_{3} \mathrm{H}$ was easily prepared by reaction of GO-HPG with 1,4-butane sultone and acidification. After successful preparation of the GO-HPG-SO $\mathrm{S}_{3} \mathrm{H}$, the catalyst was characterized by FT-IR, TGA, XRD, AFM, and FESEM.

Fig. 1a-d shows the FT-IR spectra of graphite, GO, GO-HPG, and GO-HPG-SO ${ }_{3} \mathrm{H}$ respectively. The FT-IR spectrum of graphite powder shows peaks characteristic of $\mathrm{C}=\mathrm{C}$ groups at $1573 \mathrm{~cm}^{-1}$ which the peak is not sharp (Fig. 1a). Fig. 1b shows the FT-IR spectrum of graphene oxide powder. The absorption band at $1578 \mathrm{~cm}^{-1}$ is related to $\mathrm{C}=\mathrm{C}$ double bonds which this peak is sharper than graphite due to the unsymmetry of GO. The absorption peaks at 1064, 1720 and $3410 \mathrm{~cm}^{-1}$ are assigned to C-O, carbonyl, and hydroxyl stretching mode of functional groups attachment to GO, respectively. Fig. 1c shows the FT-IR spectrum of the GO-HPG. The vibrational bands at $2922 \mathrm{~cm}^{-1}$ and $2853 \mathrm{~cm}^{-1}$ are attributed to $\mathrm{C}-\mathrm{H}$ stretching, which confirmed that the HPG has been successfully grafted on the surface of graphene oxide. In the FT-IR spectrum of the GO$\mathrm{HPG}-\mathrm{SO}_{3} \mathrm{H}$, the peaks at $1175 \mathrm{~cm}^{-1}$ and $1286 \mathrm{~cm}^{-1}$ are the symmetric and asymmetric stretching vibrations of the $\mathrm{SO}_{2}$ group, which indicate the presence of covalent $-\mathrm{SO}_{3} \mathrm{H}$ groups on the surface of nanosheets and confirms the structure of GOHPG-SO 3 H (Fig. 1d).
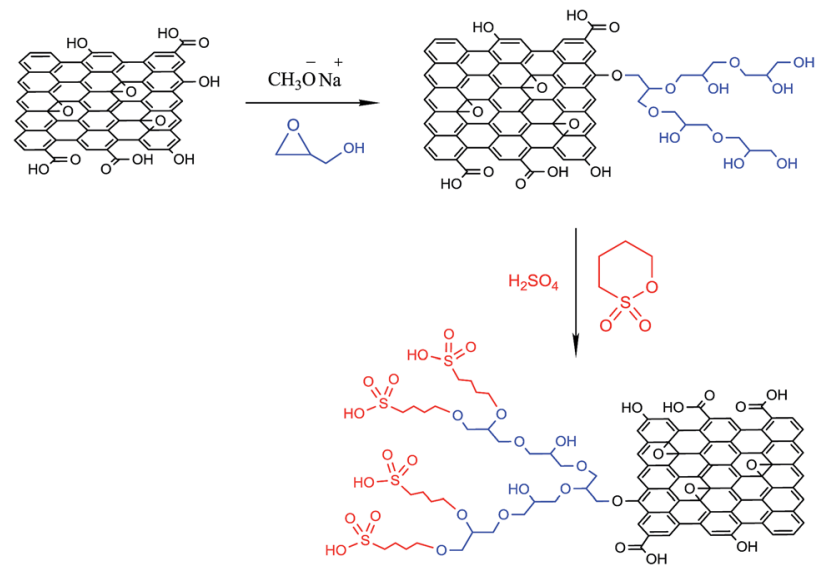

Scheme 1 Preparation of GO-HPG-SO${ }_{3} \mathrm{H}$ nanocatalyst.

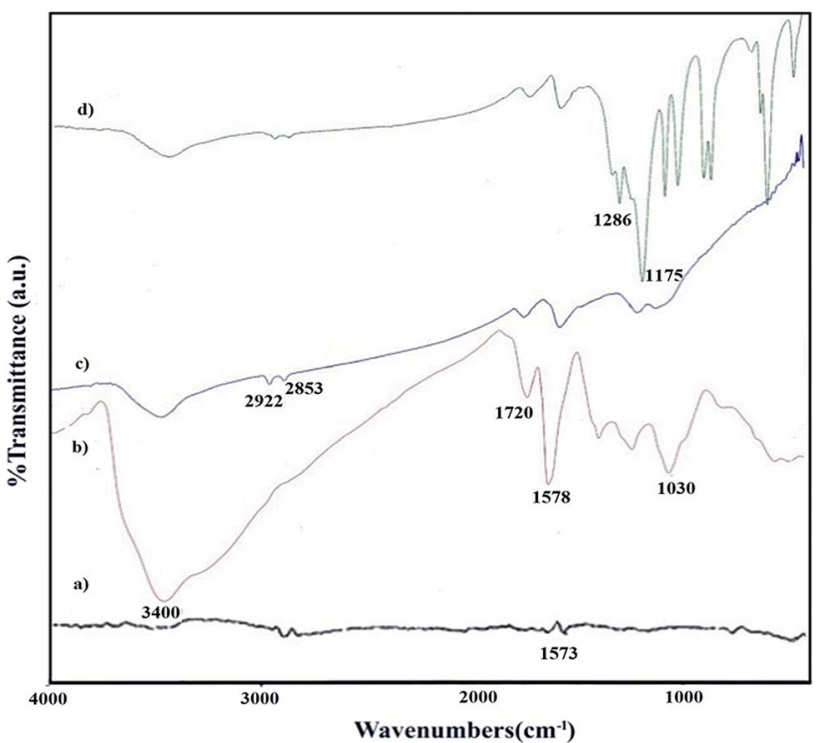

Fig. 1 FT-IR spectra of (a) graphite, (b) GO, (c) GO-HPG, and (d) GO$\mathrm{HPG}-\mathrm{SO}_{3} \mathrm{H}$.

Fig. 2 depicts XRD patterns of graphite, GO and GO-HPG$\mathrm{SO}_{3} \mathrm{H}$, respectively. The XRD pattern of graphite exhibits a peak at approximately $2 \theta=26.5^{\circ}$, corresponding to the interlayer distance of $0.335 \mathrm{~nm}$ (Fig. 2a). In Fig. 2b, the peak at $2 \theta=12.7^{\circ}$ represented graphene oxide. The interlayer spacing ( $d$-spacing) of GO is calculated $0.78 \mathrm{~nm}$ which indicated the formation of oxygen-containing functional groups between the layers of the graphite. As to the GO-HPG-SO${ }_{3} \mathrm{H}$, the strong peak at $12.7^{\circ}$ disappeared, which clearly demonstrates the HPG was successfully grafted on the GO surface, leading to a fully exfoliated structure of GO sheets and disappearance of the regular and periodic structure of graphene (Fig. 2c). ${ }^{\mathbf{9}, 30}$

In Fig. 3, the TGA thermograms of (a) GO, (b) GO-HPG and (c) GO-HPG-SO $\mathrm{S}_{3} \mathrm{H}$ are displayed. As seen from Fig. 3a, TGA curve of GO shows a weight loss about $10 \%$ below $140{ }^{\circ} \mathrm{C}$ which can be assigned to trapped water between GO nanosheets. Also, there is a major weight loss between $140{ }^{\circ} \mathrm{C}$ and $210{ }^{\circ} \mathrm{C}$ due to the decomposition of the labile oxygen-containing functional groups on the GO. ${ }^{31}$ As shown in Fig. $3 \mathrm{~b}$ and c, the GO-HPG and

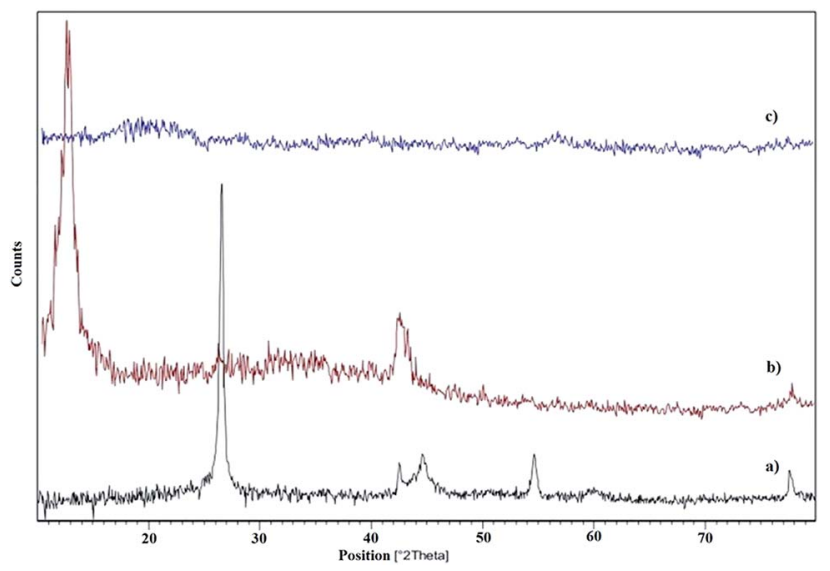

Fig. 2 XRD patterns of (a) graphite, (b) GO and (c) GO-HPG-SO${ }_{3} \mathrm{H}$. 


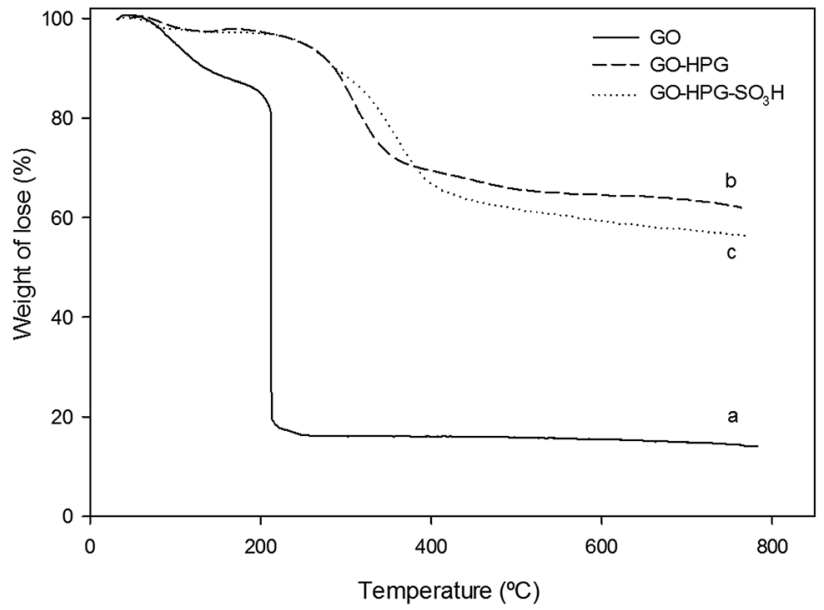

Fig. 3 TGA graph of (a) GO, (b) GO-HPG and (c) GO-HPG-SO${ }_{3} \mathrm{H}$.
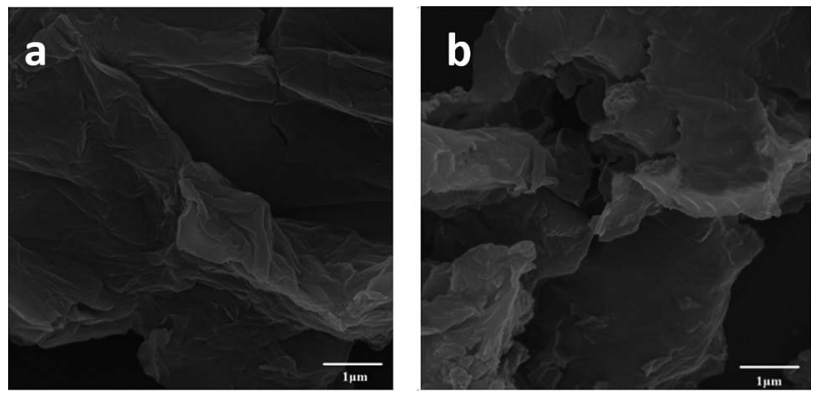

Fig. 4 FE-SEM images of (a) GO and (b) GO-HPG-SO${ }_{3} \mathrm{H}$.

GO-HPG-SO $\mathrm{S}_{3} \mathrm{H}$ are more stable than GO, which demonstrates the HPG has been successfully grafted on to the GO surface. For the GO-HPG curve, the weight loss below $100{ }^{\circ} \mathrm{C}$ is assigned to removal of physically adsorbed water. The second weight loss about $33 \%$ occur at the temperatures ranging from $260{ }^{\circ} \mathrm{C}$ to $370^{\circ} \mathrm{C}$, and it is attributed to the chemical grafting of HPG on to the GO surface (Fig. 3b). ${ }^{9}$ After reacting with butane sultone, the weight loss of the curve in Fig. $3 \mathrm{c}$ between $250-420{ }^{\circ} \mathrm{C}$ increase to $40 \%$, confirmed the sulfonation of hydroxyl groups.

The FE-SEM images of GO and GO-HPG-SO ${ }_{3} \mathrm{H}$ are shown in Fig. 4a and b. In Fig. 4a observed well-ordered two-dimensional and flake-like sheets of the GO nanosheets. Different morphologies were showed for GO and prepared catalyst. The image of the GO-HPG-SO $\mathrm{S}_{3} \mathrm{H}$ shows that the PEGylated nanosheets became wrinkled and folded during the sample preparation (Fig. 4b). ${ }^{32,33}$

Fig. 5 displays atomic force microscopy (AFM) images of GO and GO-HPG-SO $\mathrm{S}_{3} \mathrm{H}$. In Fig. 5a, we clearly detect individual single-layer GO sheets with average thickness of $1 \mathrm{~nm}$, coincident with the typical thicknesses reported previously. ${ }^{33,34}$ After the surface functionalization, the thickness of sheets is increased to $9 \mathrm{~nm}$ (Fig. 5b). The increase in the thickness of functionalized GO nanosheets can be attributed to the hyperbranched polyglycerol, which is uniformly grafted on the surface of GO nanosheets. EDS analysis was also used to characterize the GO and GO-HPG-SO ${ }_{3} \mathrm{H}$ (Fig. 6a and b). The
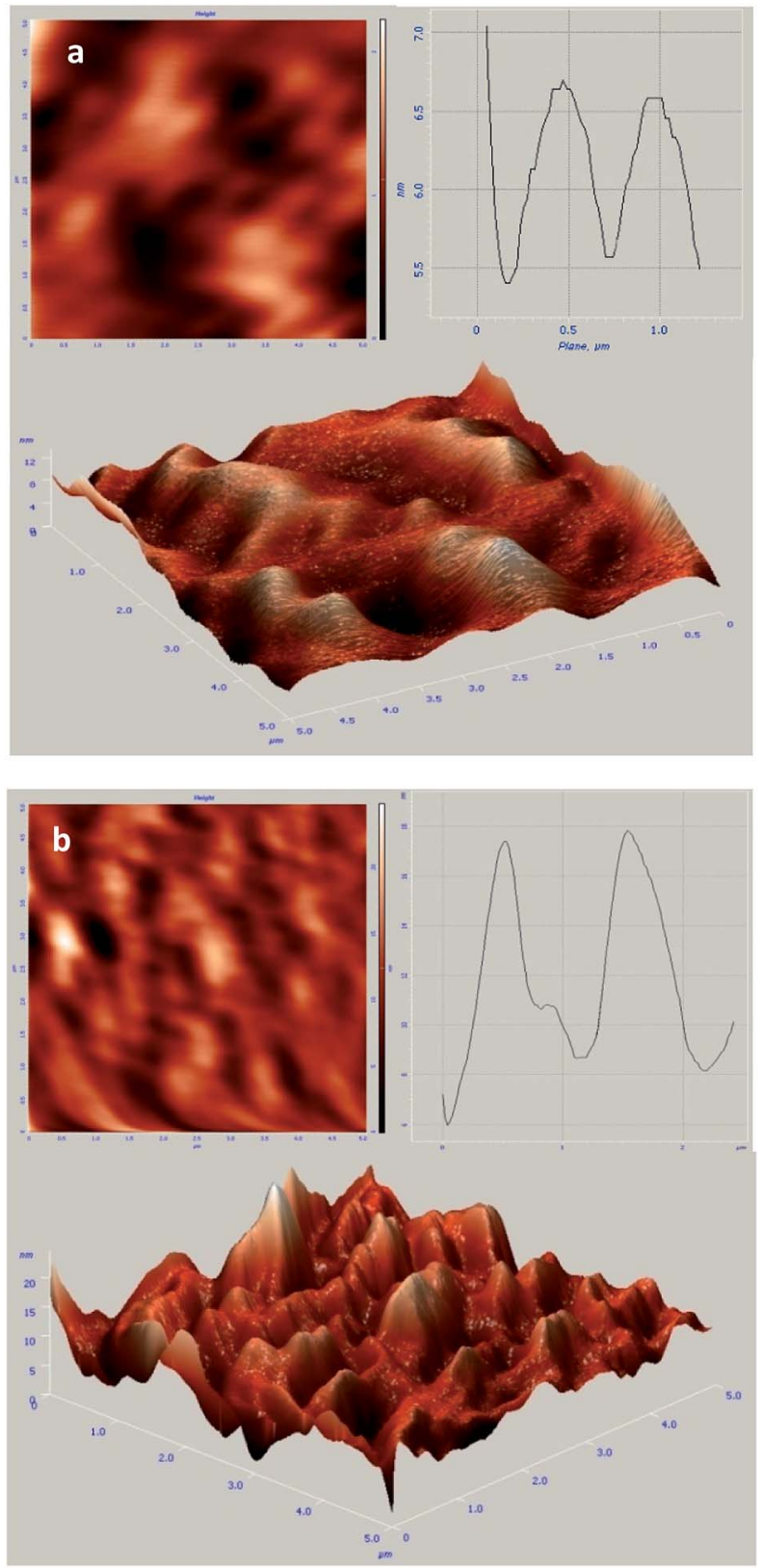

Fig. 5 AFM images of (a) GO nanosheets and (b) GO-HPG-SO${ }_{3} \mathrm{H}$.

spectrum clearly exhibit the presence of carbon, oxygen, and sulfur elements in the sample, which further confirm successful preparation of the nanocatalyst.

\section{Investigation of catalyst activity of GO-HPG-SO $\mathrm{S}_{3} \mathrm{H}$ in the synthesis of benzo[ $a]$ pyrano-[2,3-c]phenazine derivatives}

The prepared GO-HPG-SO $\mathrm{S}_{3} \mathrm{H}$ were employed in the synthesis of benzo[a]pyrano-[2,3-c]phenazine dyes. Initially, the reaction parameters were optimized in the one-pot four-component reaction of 2-hydroxy-1,4-naphthoquinone, benzene-1,2diamine, 4-chlorobenzaldehyde, malononitrile in the presence of GO-HPG-SO ${ }_{3} \mathrm{H}$ as the model reaction (Scheme 2). To choose the reaction medium, the reaction was carried out in various solvents such as $\mathrm{H}_{2} \mathrm{O}$, EtOH, $\mathrm{CH}_{3} \mathrm{CN}, \mathrm{PhCH}_{3}$, and without any 

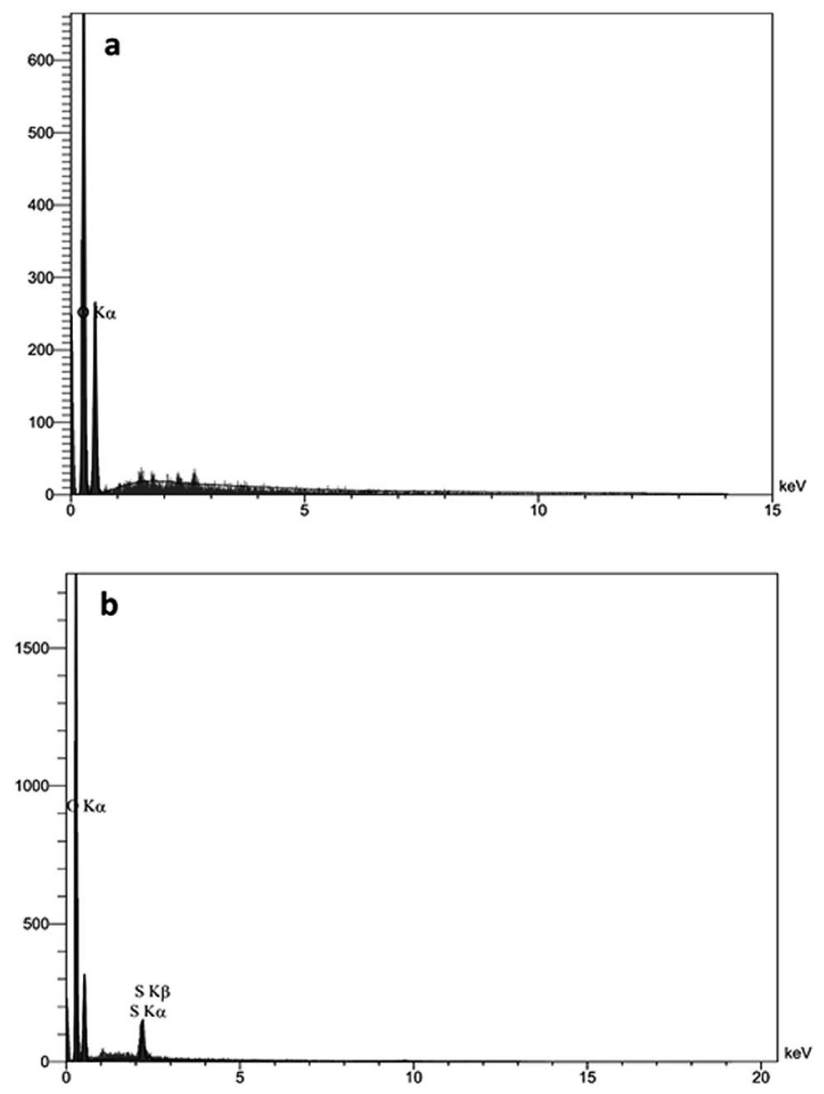

Fig. 6 EDS patterns of (a) GO and (b) GO-HPG-SO ${ }_{3} \mathrm{H}$.

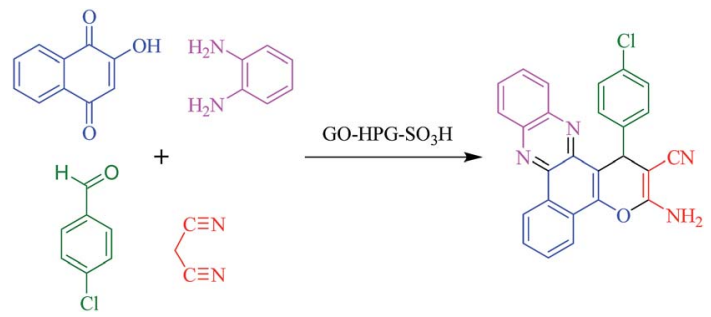

Scheme 2 Synthesis of 3-amino-1-(4-chlorophenyl)-1H-benzo[a] pyrano[2,3-c]phenazine-2-carbonitrile.

solvent (Table 1 , entries $1-5$ ). As shown in Table 1 , entry 2 , the yield of reaction under solvent free conditions is more than other solvents. Therefore, the solvent free conditions were chosen as the reaction medium.

Table 1 Optimization of the reaction in the presence of different solvents ${ }^{a}$

\begin{tabular}{lllll}
\hline Entry & Solvent & Temp. & Time $(\mathrm{min})$ & Yield $^{b}(\%)$ \\
\hline 1 & $\mathrm{H}_{2} \mathrm{O}$ & Reflux & 60 & Trace \\
2 & Solvent free & $100{ }^{\circ} \mathrm{C}$ & 30 & 95 \\
3 & EtOH & Reflux & 35 & 90 \\
4 & $\mathrm{CH}_{3} \mathrm{CN}$ & Reflux & 60 & 70 \\
5 & $\mathrm{PhCH}_{3}$ & Reflux & 75 & 35
\end{tabular}

${ }^{a}$ Reaction conditions: 2-hydroxy-1,4-naphthoquinone (1 $\left.\mathrm{mmol}\right)$, benzene-1,2-diamine $(1 \mathrm{mmol})$, aldehyde $(1 \mathrm{mmol})$, malononitrile $(1$ mmol), GO-HPG-SO ${ }_{3} \mathrm{H}(10 \mathrm{mg}) .{ }^{b}$ Isolated yields.
In order to obtain the optimal amount of the catalyst, the reaction was carried out in the presence of different amounts of catalyst (Table 2). The best result was observed with $10 \mathrm{mg}$ of the catalyst and the product yield afforded $95 \%$ at $30 \mathrm{~min}$. Also, the reaction was performed in the absence of catalyst and no product was formed.

For optimization of reaction temperature, an increase in temperature of the reaction $\left(50\right.$ to $110{ }^{\circ} \mathrm{C}$ ) led to increased rate of reaction and yields of product. At temperature of $100{ }^{\circ} \mathrm{C}$, the yield of the reaction was $95 \%$ and it similar at $110{ }^{\circ} \mathrm{C}$ (Table 3 , entries 4 and 5).

The best result was obtained with $10 \mathrm{mg}$ of GO-HPG-SO $\mathrm{SO}_{3} \mathrm{H}$ as catalyst at $100{ }^{\circ} \mathrm{C}$ under solvent-free conditions afforded 3amino-2-cyano-1-(4-chlorophenyl)-1 $H$-benzo[a]pyrano[2,3-c] phenazine in 30 min with $95 \%$ yield. After optimization of the reaction conditions, synthesis of benzo[a]pyrano-[2,3-c]phenazine derivatives were performed for a series of different aromatic aldehydes containing electron-releasing and electronwithdrawing substituents to investigate the versatility of the protocol under GO-HPG-SO ${ }_{3} \mathrm{H}$ catalysis. As shown in Table 4, aromatic aldehydes containing electron-withdrawing groups reacted rapidly and gave higher yields, while substitutions of electron-rich groups on the benzene ring required longer reaction times and got lower yields. Furthermore, the structures of these products were supported by ${ }^{1} \mathrm{H}$ NMR spectra.

The reaction of benzo[ $a]$ pyrano- $[2,3-c]$ phenazine derivatives has been investigated with various catalysts in literature and compared with the present method (Table 5). It was found that our reported method, using GO-HPG-SO $\mathrm{S}_{3} \mathrm{H}$ as the catalyst, is simple, effective, applicable and comparable with many catalytic systems for the synthesis of benzo[a]pyrano-[2,3-c]phenazine derivatives.

Table 2 The optimization of GO-HPG-SO ${ }_{3} \mathrm{H}$ catalyst amount ${ }^{a}$

\begin{tabular}{llcl}
\hline Entry & Catalyst $(\mathrm{mg})$ & Time $(\mathrm{min})$ & Yield $^{b}(\%)$ \\
\hline 1 & 0 & 120 & - \\
2 & 2 & 50 & 75 \\
3 & 5 & 35 & 87 \\
4 & 10 & 30 & 95 \\
5 & 15 & 30 & 95
\end{tabular}

${ }^{a}$ Reaction conditions: 2-hydroxy-1,4-naphthoquinone (1 mmol), benzene-1,2-diamine $(1 \mathrm{mmol})$, aldehyde $(1 \mathrm{mmol})$, malononitrile $(1$ $\mathrm{mmol})$, solvent free, $100{ }^{\circ} \mathrm{C} .{ }^{b}$ Isolated yields.

Table 3 Temperature optimization for the synthesis of benzo[a]pyrano-[2,3-c]phenazine derivatives ${ }^{a}$

\begin{tabular}{llll}
\hline Entry & $T\left({ }^{\circ} \mathrm{C}\right)$ & Time $(\mathrm{min})$ & Yield $^{b}(\%)$ \\
\hline 1 & 50 & 60 & 50 \\
2 & 80 & 60 & 75 \\
3 & 90 & 40 & 90 \\
4 & 100 & 30 & 95 \\
5 & 110 & 30 & 95
\end{tabular}

${ }^{a}$ Reaction conditions: 2-hydroxy-1,4-naphthoquinone (1 $\left.\mathrm{mmol}\right)$, benzene-1,2-diamine $(1 \mathrm{mmol})$, aldehyde $(1 \mathrm{mmol})$, malononitrile $(1$ $\mathrm{mmol})$, solvent free, GO-HPG-SO $\mathrm{S}_{3} \mathrm{H}(10 \mathrm{mg}) .{ }^{b}$ Isolated yields. 
Table 4 Synthesis of benzo[a]pyrano-[2,3-c]phenazine derivatives catalyzed by GO-HPG-SO ${ }_{3} \mathrm{H}^{a}$

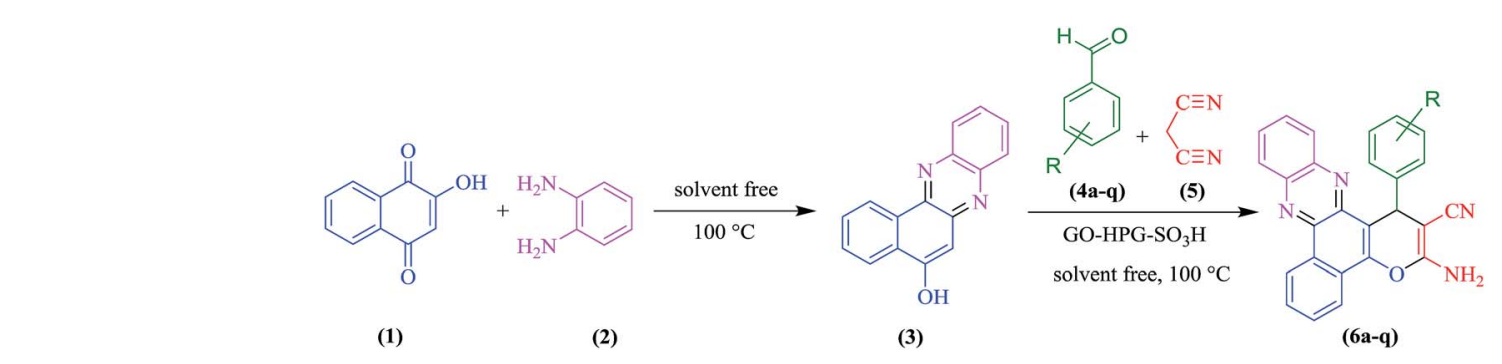

\begin{tabular}{|c|c|c|c|c|c|c|}
\hline Entry & Aldehyde & Product & $T(\min )$ & Yield $^{b}(\%)$ & $\mathrm{TON}^{c}$ & $\operatorname{TOF}^{d}\left(\mathrm{~h}^{-1}\right)$ \\
\hline 1 & & & 45 & 91 & 114 & 152 \\
\hline 2 & & & 40 & 87 & 109 & 165 \\
\hline 3 & & & 45 & 89 & 111 & 148 \\
\hline 4 & & & 30 & 95 & 119 & 238 \\
\hline 5 & & & 30 & 93 & 116 & 232 \\
\hline 6 & & & 45 & 89 & 111 & 148 \\
\hline
\end{tabular}


Table 4 (Contd.)

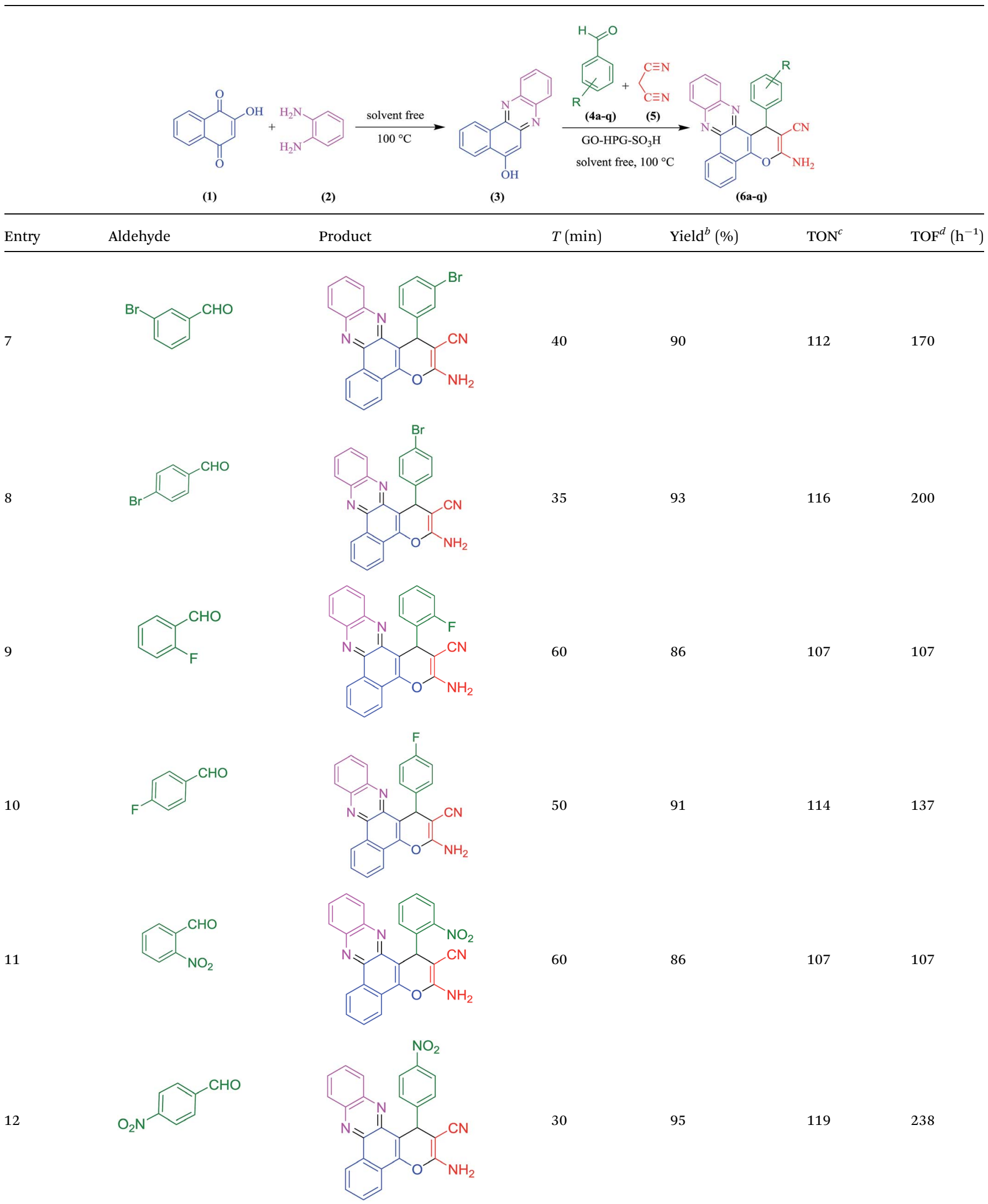


Table 4 (Contd.)

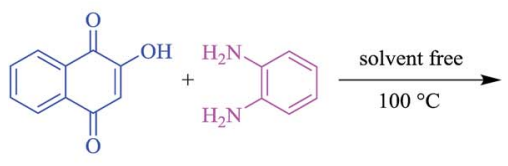

(1)
(2)

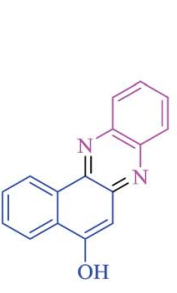

(3)

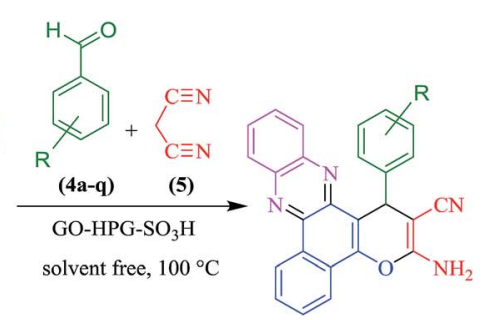

$(6 a-q)$

\begin{tabular}{|c|c|c|c|c|c|c|}
\hline Entry & Aldehyde & Product & $T(\min )$ & $\operatorname{Yield}^{b}(\%)$ & $\mathrm{TON}^{c}$ & $\operatorname{TOF}^{d}\left(\mathrm{~h}^{-1}\right)$ \\
\hline 13 & & & 40 & 90 & 112 & 170 \\
\hline 14 & & & 45 & 85 & 106 & 141 \\
\hline 15 & & & 50 & 87 & 109 & 131 \\
\hline 16 & & & 45 & 85 & 106 & 141 \\
\hline 17 & & & 40 & 87 & 109 & 165 \\
\hline
\end{tabular}

${ }^{a}$ Reaction conditions: 2-hydroxy-1,4-naphthoquinone (1 mmol), benzene-1,2-diamine ( $\left.1 \mathrm{mmol}\right)$, aldehyde (1 mmol), malononitrile (1 mmol), GOHPG-SO $\mathrm{S}_{3} \mathrm{H}(10 \mathrm{mg})$, solvent free, $100{ }^{\circ} \mathrm{C} .{ }^{b}$ Isolated yields. ${ }^{c}$ TON: mole of formed benzo $[a]$ pyrano-[2,3-c]phenazine derivatives per mole of catalyst. ${ }^{d}$ TOF $\left(\mathrm{h}^{-1}\right):$ (mmol of product/mmol of active site of catalyst)/time of the reaction (h).

As shown in Fig. 7, we studied the reusability of GO-HPG$\mathrm{SO}_{3} \mathrm{H}$ as heterogeneous catalyst for the same reactants. After completion of the reaction, the catalyst was isolated by filtration, washed exhaustively with acetone, chloroform, and ethanol and drying at $80{ }^{\circ} \mathrm{C}$ in an oven for $24 \mathrm{~h}$ for subsequent experiments to check its reusability under similar reaction conditions. It was observed that the recovered catalyst could be reused five times without significant loss of its catalytic activity. 
Table 5 Comparison of the efficiencies of various catalysts used in the synthesis of benzo[a]pyrano-[2,3-c]phenazines

\begin{tabular}{|c|c|c|c|c|c|}
\hline Entry & Catalyst & Condition & Time (min) & Yield (\%) & Ref. \\
\hline 1 & HOAC & HOAC/r.t. & 10 & 89 & 25 \\
\hline 2 & $\mathrm{CuO}$ & Solvent free $/ 75^{\circ} \mathrm{C}$ & 7 & 94 & 35 \\
\hline 4 & Theophylline & Water $/ 70{ }^{\circ} \mathrm{C}$ & 180 & 89 & 36 \\
\hline 5 & GO-HPG-SO ${ }_{3} \mathrm{H}$ & Solvent free $/ 100^{\circ} \mathrm{C}$ & 30 & 95 & This work \\
\hline
\end{tabular}

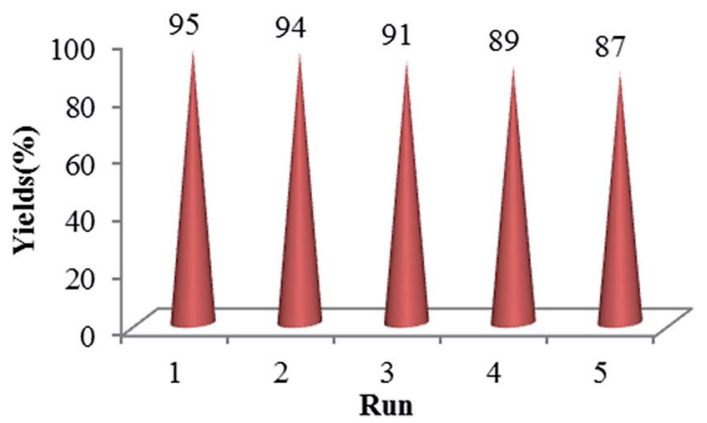

Fig. 7 The reusability of the catalyst $\mathrm{GO}-\mathrm{HPG}-\mathrm{SO}_{3} \mathrm{H}$ in the synthesis of benzo[a]pyrano-[2,3-c]phenazine derivatives.

\section{The proposed reaction mechanism}

A plausible mechanism for the synthesis of benzo[a]pyrano-[2,3c]phenazines according the previously reported works ${ }^{26,27}$ is depicted in Scheme 3. Firstly, 2-hydroxy-1,4-naphthoquinone tautomerizes to intermediate (I). The primary condensation of intermediate (I) with benzene-1,2-diamine obtain benzo[ $[a]$ phenazin-5-ol (II). On this mechanism, the GO-HPG-SO ${ }_{3} \mathrm{H}$ catalyst activates the carbonyl group of the aromatic aldehyde to afford intermediate (III). The Knoevenagel condensation of intermediate (III) and malononitrile forms the arylidene malononitrile (IV). Subsequently, the Michael addition of $6 \mathrm{H}$-benzo [a] phenazin-5-ol (II) with intermediate (IV) in the presence of

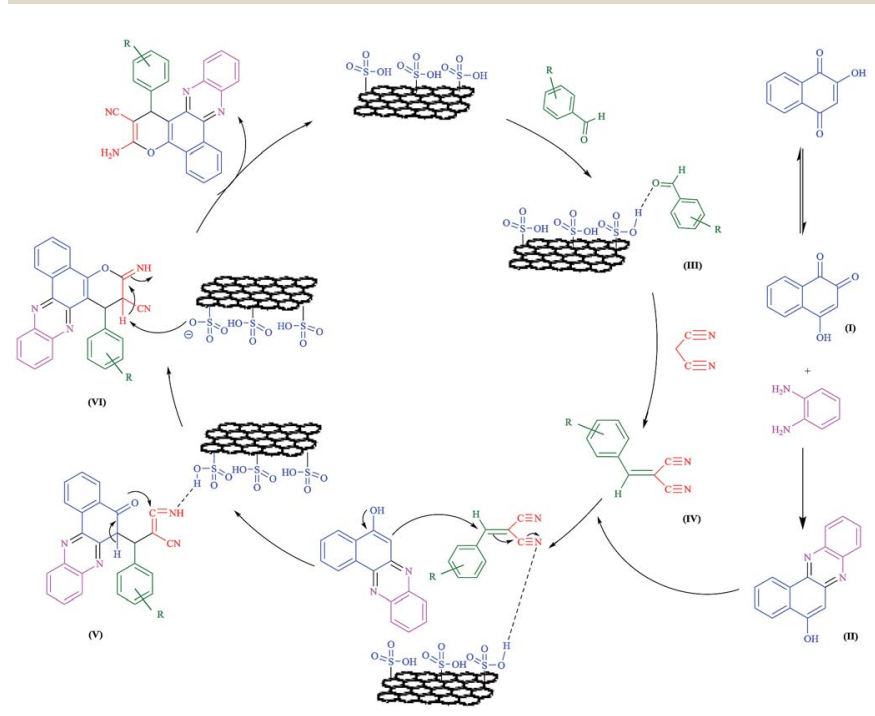

Scheme 3 Proposed mechanism for synthesis of benzo[a]pyrano$[2,3-c]$ phenazine derivatives.
GO-HPG-SO $\mathrm{S}_{3} \mathrm{H}$ catalyst give intermediate (V). The intermediate (V) undergo tautomerization and intramolecular cyclization using GO-HPG-SO $\mathrm{SO}_{3} \mathrm{H}$ catalyst to form intermediate (VI). Ultimately, after tautomerization of intermediate (VI), benzo $[a]$ pyrano-[2,3-c]phenazines are formed in high yield and short reaction times.

\section{Conclusion}

In this research, we have prepared an acid heterogeneous catalyst for the synthesis of benzo[ $a]$ pyrano-[2,3-c]phenazines under green condition. After optimization of the reaction conditions, the catalytic reaction was performed with $10 \mathrm{mg}$ of GO-HPG-SO $\mathrm{S}_{3} \mathrm{H}$ as a catalyst at $100{ }^{\circ} \mathrm{C}$ under solvent-free conditions in high to excellent yields and short times. In this reaction, multisulfonate hyperbranched polyglycerol modified graphene oxide has been used as a highly efficient, inexpensive and non-toxic catalyst. The catalyst was characterized by FT-IR, TGA, XRD, AFM, and FESEM techniques. Furthermore, the products can be easily separated from the reaction mixture by a simple purification process. Also, the catalyst was recycled and reused for five times without remarkable loss of catalytic activity.

\section{Experimental}

\section{Materials and apparatus}

The chemicals were purchased from Fluka and Merck Chemical Companies and used without purification. IR spectra were obtained as $\mathrm{KBr}$ pellets on a Perkin-Elmer 781 spectrophotometer and on an impact 400 Nicolet FT-IR spectrophotometer. ${ }^{1} \mathrm{H}$ NMR was recorded in DMSO- $d_{6}$ solvent on a Bruker DRX-400 spectrometer with tetramethylsilane as internal reference. XRD patterns were obtained by an X'PertPro (Philips) instrument with $1.54{ }^{\circ} \mathrm{A}$ wavelengths of X-ray beam and $\mathrm{Cu}$ anode material, at a scanning speed of $2^{\circ} \mathrm{min}^{-1}$ from $10^{\circ}$ to $80^{\circ}(2 \theta)$. Thermogravimetric analysis (TGA) was performed on a mettler TA4000 system TG-50 at a heating rate of $10 \mathrm{~K} \mathrm{~min}^{-1}$ under $\mathrm{N}_{2}$ atmosphere. The SEM images of catalysts were recorded on a FE-SEM Hitachi S4160 instrument. The AFM image of catalysts was investigated using scanning probe microscopy (SPM9600, Shimadzu). Melting points were measured with a Yanagimoto micro melting point apparatus. The purity determination of the substrates and reaction monitoring were accomplished by TLC on silica-gel polygram SILG/UV 254 plates (from Merck Company). 


\section{Preparation of graphene oxide}

The graphene oxide nanosheets were synthesized by a modified Hummer's method. Typically, in a $1000 \mathrm{~mL}$ round-bottom flask equipped with a magnetic bar, a mixture of $5.0 \mathrm{~g}$ of natural graphite powder and $2.5 \mathrm{~g}$ of sodium nitrate and $115 \mathrm{~mL}$ of sulfuric acid (98\%) were placed in an ice bath. Then, $15.0 \mathrm{~g}$ of potassium permanganate was slowly added to obtained solution and stirred for $2 \mathrm{~h}$. The mixture solution was taken to a water bath $\left(35^{\circ} \mathrm{C}\right)$ and stirred for $30 \mathrm{~min}$. Then, deionized water $(230 \mathrm{~mL})$ was slowly added and the solution temperature was about $98{ }^{\circ} \mathrm{C}$ and stirred for $15 \mathrm{~min}$. Afterward, $700 \mathrm{~mL}$ of deionized water and $50 \mathrm{~mL}$ of $\mathrm{H}_{2} \mathrm{O}_{2}(30 \%)$ was added to the solution respectively. The resulting materials were filtered and washed by diluted $\mathrm{HCl}(5 \%)$ and deionized water for several times. Then graphite oxide powder was obtained after drying for $12 \mathrm{~h}$ at $60{ }^{\circ} \mathrm{C}$ under vacuum. The graphite oxide powder was dispersed in distilled water to make concentration of $0.5 \mathrm{mg}$ $\mathrm{mL}^{-1}$ and exfoliated by ultrasonication to obtain GO nanosheets.

\section{Grafting of hyperbranched polyglycerol on GO nanosheets}

The hyperbranched polyglycerol modified GO nanosheets were prepared according to the reported protocol with minor revision. ${ }^{37}$ A saturated solution of potassium methoxide in methanol was mixed with $0.2 \mathrm{~g}$ of graphene oxide nanosheets. The mixture was sonicated in an ultrasonic bath for $30 \mathrm{~min}$ and stirred at room temperature for $2 \mathrm{~h}$. Then, mixture was refluxed at $80{ }^{\circ} \mathrm{C}$ for $4 \mathrm{~h}$. After completion of the reaction, graphene oxide nanosheets were washed with methanol and dried in a vacuum oven at $60{ }^{\circ} \mathrm{C}$. The glycidol $(4 \mathrm{~mL})$ was added slowly to deprotonated nanosheets at $100{ }^{\circ} \mathrm{C}$ and the mixture was stirred at $100{ }^{\circ} \mathrm{C}$ for $8 \mathrm{~h}$. Then it was cooled and the mixture was dissolved in methanol. After repeated wash by methanol followed by drying overnight under vacuum, HPG grafted on graphene oxide nanosheets (GO-HPG) was obtained. The synthesis of hyperbranched polyglycerol functionalized graphene oxide was confirmed by IR and TGA.

\section{Preparation of GO-HPG-SO ${ }_{3} \mathrm{H}$}

In a round-bottomed flask GO-HPG $(0.2 \mathrm{~g})$ was dispersed in toluene at room temperature and 1,4-butane sultone $(0.2 \mathrm{~mL})$ was slowly added. The mixture was stirred at $50{ }^{\circ} \mathrm{C}$ for $24 \mathrm{~h}$. The resulting solid was isolated by filtration, washed with ethanol, and dried under vacuum at $55^{\circ} \mathrm{C}$. After that, excess sulfuric acid solution in water was slowly added, and the mixture was stirred at $60^{\circ} \mathrm{C}$ for $12 \mathrm{~h}$ to complete the reaction. Subsequently formed mixture was washed several times with deionized water and dried under vacuum at $55{ }^{\circ} \mathrm{C}$ for $24 \mathrm{~h}$.

\section{Determination of the acidity of the GO-HPG- $\mathrm{SO}_{3} \mathrm{H}$ catalyst}

For evaluation of the acidity of the GO-HPG-SO ${ }_{3} \mathrm{H}, 25 \mathrm{~mL}$ aqueous $\mathrm{NaCl}$ (1 M, pH 6.7) was prepared and $20 \mathrm{mg}$ GOHPG-SO $\mathrm{S}_{3} \mathrm{H}$ was added and stirred for $4 \mathrm{~h} .{ }^{38}$ The $\mathrm{pH}$ of solution decreased to 3.2 , which is equivalent to $0.8 \mathrm{mmol}$ $\mathrm{g}^{-1} \mathrm{H}^{+}$.
General procedure for the preparation of benzo $[a]$ pyrano- $[2,3-$ c]phenazine derivatives catalyzed by GO-HPG-SO $\mathrm{S}_{3} \mathrm{H}$ under thermal conditions

A mixture of 2-hydroxy-1,4-naphthoquinone $(1 \mathrm{mmol})$ and benzene-1,2-diamine $(1 \mathrm{mmol})$ were heated at $100{ }^{\circ} \mathrm{C}$ and solvent free conditions until in less than $5 \mathrm{~min}$ an orange solid of benzo[a]phenazine was formed. Afterward, aldehydes (1 $\mathrm{mmol})$, malononitrile (1 mmol), and GO-HPG-SO ${ }_{3} \mathrm{H}(10 \mathrm{mg})$ were added into the reaction system and this mixture was stirred at $100{ }^{\circ} \mathrm{C}$ for the appropriate time according to Table 4 . After completion of the reaction, monitored by TLC, the reaction mixture was allowed to cool to room temperature. Then, the mixture was diluted with dichloromethane and the catalyst was filtered and washed with chloroform and EtOH $(2 \times 5 \mathrm{~mL})$ for checking the reusability. The solution was recovered via evaporation using a rotary evaporator. The solid was recrystallized with hot ethanol to give the pure solid. The analytical and spectroscopic data for products:

3-Amino-1-phenyl-1H-benzo[ $a]$ pyrano[2,3-c]phenazine-2carbonitrile (6a). Yellow solid, mp: $300-303{ }^{\circ} \mathrm{C}$ (lit. 25: 298-300 $\left.{ }^{\circ} \mathrm{C}\right)$; IR (KBr, $\nu, \mathrm{cm}^{-1}$ ): 3443, 3312, 3174, 3055, 2188, 1659, 1623, 1593, 1493, 1397; ${ }^{1} \mathrm{H}$ NMR (400 MHz, DMSO- $\left.d_{6}\right)(\delta, \mathrm{ppm}): 5.49$ $(\mathrm{s}, 1 \mathrm{H}), 7.08\left(\mathrm{t}, J^{3}=8.0 \mathrm{~Hz}, 1 \mathrm{H}\right), 7.21\left(\mathrm{t}, J^{3}=8.0 \mathrm{~Hz}, 2 \mathrm{H}\right), 7.28(\mathrm{~m}$, $\left.\mathrm{NH}_{2}\right), 7.39\left(\mathrm{~d}, J^{3}=8.0 \mathrm{~Hz}, 2 \mathrm{H}\right), 7.90-7.94(\mathrm{~m}, 3 \mathrm{H}), 7.98\left(\mathrm{t}, J^{3}=\right.$ $8.0 \mathrm{~Hz}, 1 \mathrm{H}), 8.13-8.15(\mathrm{~m}, 1 \mathrm{H}), 8.24-8.26(\mathrm{~m}, 1 \mathrm{H}), 8.43\left(\mathrm{~d}, J^{3}=\right.$ $8.0 \mathrm{~Hz}, 1 \mathrm{H}), 9.21\left(\mathrm{~d}, J^{3}=8.0 \mathrm{~Hz}, 1 \mathrm{H}\right)$.

3-Amino-1-(4-(dimethylamino)phenyl)-1H-benzo[a]pyrano [2,3-c]phenazine-2-carbonitrile (6b). Orange solid, mp: 259$263{ }^{\circ} \mathrm{C}$ (lit. 25: 261-263 ${ }^{\circ} \mathrm{C}$ ); IR (KBr, $\left.\nu, \mathrm{cm}^{-1}\right)$ : 3463, 3310, 3061, 2208, 1628, 1594, 1533, 1458, 1351; ${ }^{1} \mathrm{H}$ NMR (400 MHz, DMSO$\left.d_{6}\right)(\delta, \mathrm{ppm}): 3.38(\mathrm{~s}, 6 \mathrm{H}), 6.84\left(\mathrm{~m}, \mathrm{NH}_{2}\right), 7.19(\mathrm{~s}, 1 \mathrm{H}), 7.80-7.91$ $(\mathrm{m}, 6 \mathrm{H}), 8.15\left(\mathrm{~d}, J^{3}=8.0 \mathrm{~Hz}, 1 \mathrm{H}\right), 8.28\left(\mathrm{~d}, J^{3}=8.0 \mathrm{~Hz}, 1 \mathrm{H}\right), 8.30-$ $8.32(\mathrm{~m}, 2 \mathrm{H}), 9.25-9.27(\mathrm{~m}, 1 \mathrm{H}), 11.55(\mathrm{~s}, 1 \mathrm{H})$.

3-Amino-1-(2-chlorophenyl)-1H-benzo[a]pyrano[2,3-c] phenazine-2-carbonitrile (6c). Yellow solid, mp: $300-304{ }^{\circ} \mathrm{C}$; IR $\left(\mathrm{KBr}, \nu, \mathrm{cm}^{-1}\right): 3464,3312,3170,3057,2191,1658,1623,1590$, 1470, 1387; ${ }^{1} \mathrm{H}$ NMR (400 MHz, DMSO- $\left.d_{6}\right)(\delta, \mathrm{ppm}): 5.92(\mathrm{~s}, 1 \mathrm{H})$, 7.08-7.10 (m, 2H), 7.18-7.19 (m, 1H), $7.33\left(\mathrm{~m}, \mathrm{NH}_{2}\right), 7.38-7.40$ $(\mathrm{m}, 1 \mathrm{H}), 7.89-8.02(\mathrm{~m}, 5 \mathrm{H}), 8.22-8.24(\mathrm{~m}, 1 \mathrm{H}), 8.44\left(\mathrm{~d}, J^{3}=\right.$ $8.0 \mathrm{~Hz}, 1 \mathrm{H}), 9.21\left(\mathrm{~d}, J^{3}=8.0 \mathrm{~Hz}, 1 \mathrm{H}\right)$.

3-Amino-1-(4-chlorophenyl)-1H-benzo[a]pyrano[2,3-c] phenazine-2-carbonitrile (6d). Yellow solid, mp: $285-290{ }^{\circ} \mathrm{C}$ (lit. 25: 288-291 $\left.{ }^{\circ} \mathrm{C}\right)$; IR (KBr, $\left.\nu, \mathrm{cm}^{-1}\right)$ : 3464, 3311, 3173, 3057, 2188, 1659, 1623, 1593, 1489, 1402, 1385; ${ }^{1} \mathrm{H}$ NMR (400 MHz, DMSO$\left.d_{6}\right)(\delta, \mathrm{ppm}): 5.45(\mathrm{~s}, 1 \mathrm{H}), 7.26\left(\mathrm{~d}, J^{3}=8.0 \mathrm{~Hz}, 2 \mathrm{H}\right), 7.32\left(\mathrm{~s}, \mathrm{NH}_{2}\right)$, $7.41\left(\mathrm{~d}, J^{3}=8.0 \mathrm{~Hz}, 2 \mathrm{H}\right), 7.89-7.93(\mathrm{~m}, 2 \mathrm{H}), 7.96-8.0(\mathrm{~m}, 2 \mathrm{H})$, 8.08-8.10 (m, 1H), 8.22-8.23 (m, 1H), $8.41\left(\mathrm{~d}, J^{3}=8.0 \mathrm{~Hz}, 1 \mathrm{H}\right)$, $9.18\left(\mathrm{~d}, J^{3}=8.0 \mathrm{~Hz}, 1 \mathrm{H}\right)$.

3-Amino-1-(2,4-dichlorophenyl)-1H-benzo[a]pyrano[2,3-c] phenazine-2-carbonitrile (6e). Brown solid, mp: $307-310{ }^{\circ} \mathrm{C}$ (lit. 39: $\left.308-310^{\circ} \mathrm{C}\right)$; IR (KBr, $\left.\nu, \mathrm{cm}^{-1}\right): 3478,3313,3168,3069,2186$, 1659, 1624, 1589, 1468, 1403, 1385; ${ }^{1} \mathrm{H}$ NMR (400 MHz, DMSO$\left.d_{6}\right)(\delta, \mathrm{ppm}): 5.84(\mathrm{~s}, 1 \mathrm{H}), 7.14\left(\mathrm{~d}, J^{3}=8.0 \mathrm{~Hz}, 1 \mathrm{H}\right), 7.20\left(\mathrm{~d}, J^{3}=\right.$ $8.0 \mathrm{~Hz}, 1 \mathrm{H}), 7.40\left(\mathrm{~s}, \mathrm{NH}_{2}\right), 7.54(\mathrm{~s}, 1 \mathrm{H}), 7.88-8.0(\mathrm{~m}, 5 \mathrm{H}), 8.21-$ $8.23(\mathrm{~m}, 1 \mathrm{H}), 8.41\left(\mathrm{~d}, J^{3}=8.0 \mathrm{~Hz}, 1 \mathrm{H}\right), 9.19\left(\mathrm{~d}, J^{3}=8.0 \mathrm{~Hz}, 1 \mathrm{H}\right)$. 
3-Amino-1-(2-bromophenyl)-1H-benzo[a]pyrano[2,3-c] phenazine-2-carbonitrile (6f). Brown solid, mp: $284-286{ }^{\circ} \mathrm{C}$; IR $\left(\mathrm{KBr}, \nu, \mathrm{cm}^{-1}\right): 3464,3311,3169,3055,2191,1659,1623,1589$, 1467, 1387; ${ }^{1} \mathrm{H}$ NMR (400 MHz, DMSO- $\left.d_{6}\right)(\delta, \mathrm{ppm}): 5.88(\mathrm{~s}, 1 \mathrm{H})$, 6.97-7.01 (m, 1H), $7.10(\mathrm{~m}, 2 \mathrm{H}), 7.36\left(\mathrm{~s}, \mathrm{NH}_{2}\right), 7.57\left(\mathrm{~d}, J^{3}=\right.$ $8.0 \mathrm{~Hz}, 1 \mathrm{H}), 7.87-7.89(\mathrm{~m}, 2 \mathrm{H}), 7.93\left(\mathrm{t}, J^{3}=8.0 \mathrm{~Hz}, 2 \mathrm{H}\right), 7.99-$ $8.01(\mathrm{~m}, 1 \mathrm{H}), 8.18-8.20(\mathrm{~m}, 1 \mathrm{H}), 8.42\left(\mathrm{~d}, J^{3}=8.0 \mathrm{~Hz}, 1 \mathrm{H}\right), 9.17(\mathrm{~d}$, $\left.J^{3}=8.0 \mathrm{~Hz}, 1 \mathrm{H}\right)$.

3-Amino-1-(3-bromophenyl)-1H-benzo[a]pyrano[2,3-c] phenazine-2-carbonitrile (6g). Brown solid, mp: $268-269{ }^{\circ} \mathrm{C}$; IR $\left(\mathrm{KBr}, \nu, \mathrm{cm}^{-1}\right): 3486,3302,3171,3060,2197,1662,1627,1591$, 1471,$1385 ;{ }^{1} \mathrm{H}$ NMR (400 MHz, DMSO- $\left.d_{6}\right)(\delta, \mathrm{ppm}): 5.51(\mathrm{~s}$, $1 \mathrm{H}), 7.19-7.23(\mathrm{~m}, 1 \mathrm{H}), 7.29-7.33(\mathrm{~m}, 1 \mathrm{H}), 7.40-7.44(\mathrm{~m}, 1 \mathrm{H})$, 7.46-7.49 (m, $\left.\mathrm{NH}_{2}\right), 7.61-7.63(\mathrm{~m}, 1 \mathrm{H}), 7.95-8.02(\mathrm{~m}, 4 \mathrm{H}), 8.14-$ 8.17 (m, 1H), 8.27-8.31 (m, 1H), 8.43-8.48 (m, 1H), 9.22-9.26 (m, 1H).

3-Amino-1-(4-bromophenyl)-1H-benzo[a]pyrano[2,3-c] phenazine-2-carbonitrile (6h). Yellow solid, mp: $280-285{ }^{\circ} \mathrm{C}$ (lit. 25: $\left.283-285^{\circ} \mathrm{C}\right)$; IR ( $\left.\mathrm{KBr}, \nu, \mathrm{cm}^{-1}\right): 3467,3320,3173,3056,2187$, 1660, 1623, 1591, 1485, 1401, 1384; ${ }^{1} \mathrm{H}$ NMR (400 MHz, DMSO$\left.d_{6}\right)(\delta, \mathrm{ppm}): 5.44(\mathrm{~s}, 1 \mathrm{H}), 7.35\left(\mathrm{~d}, J^{3}=8.0 \mathrm{~Hz}, 2 \mathrm{H}\right), 7.40\left(\mathrm{~d}, J^{3}=\right.$ $8.0 \mathrm{~Hz}, 2 \mathrm{H}), 7.43\left(\mathrm{~s}, \mathrm{NH}_{2}\right), 7.92-7.98(\mathrm{~m}, 4 \mathrm{H}), 8.09-8.10(\mathrm{~m}, 1 \mathrm{H})$, $8.22-8.23(\mathrm{~m}, 1 \mathrm{H}), 8.42\left(\mathrm{~d}, J^{3}=8.0 \mathrm{~Hz}, 1 \mathrm{H}\right), 9.19\left(\mathrm{~d}, J^{3}=8.0 \mathrm{~Hz}\right.$, $1 \mathrm{H})$.

3-Amino-1-(2-fluorophenyl)-1 H-benzo[a]pyrano[2,3-c] phenazine-2-carbonitrile (6i). Yellow solid, mp: $270-272{ }^{\circ} \mathrm{C}$; IR $\left(\mathrm{KBr}, \nu, \mathrm{cm}^{-1}\right): 3449,3312,3058,2189,1661,1625,1591,1490$, 1406, 1387; ${ }^{1} \mathrm{H}$ NMR (400 MHz, DMSO- $\left.d_{6}\right)(\delta, \mathrm{ppm}): 5.75(\mathrm{~s}, 1 \mathrm{H})$, 7.0-7.16 (m, 2H), 7.26-7.34 (m, 2H), $7.38\left(\mathrm{~s}, \mathrm{NH}_{2}\right), 7.90-8.0(\mathrm{~m}$, $4 \mathrm{H}), 8.26-8.29(\mathrm{~m}, 1 \mathrm{H}), 8.32-8.36(\mathrm{~m}, 1 \mathrm{H}), 8.46\left(\mathrm{~d}, J^{3}=8.0 \mathrm{~Hz}\right.$, $1 \mathrm{H}), 9.24\left(\mathrm{~d}, J^{3}=8.0 \mathrm{~Hz}, 1 \mathrm{H}\right)$.

3-Amino-1-(4-fluorophenyl)-1 $\boldsymbol{H}$-benzo[a]pyrano $[2,3-c]$ phenazine-2-carbonitrile (6j). Yellow solid, mp: $275-280{ }^{\circ} \mathrm{C}$ (lit. 25: $\left.274-276{ }^{\circ} \mathrm{C}\right)$; IR ( $\left.\mathrm{KBr}, \nu, \mathrm{cm}^{-1}\right): 3459,3315,3174,3052$, 2190, 1660, 1623, 1593, 1502, 1402, 1385; ${ }^{1} \mathrm{H}$ NMR $(400 \mathrm{MHz}$, DMSO- $\left.d_{6}\right)(\delta, \mathrm{ppm}): 5.49(\mathrm{~s}, 1 \mathrm{H}), 7.03\left(\mathrm{t}, J^{3}=8.0 \mathrm{~Hz}, 2 \mathrm{H}\right), 7.41-$ $7.45\left(\mathrm{~m}, 2 \mathrm{H}-\mathrm{Ar}\right.$ and $\left.2 \mathrm{H}-\mathrm{NH}_{2}\right), 7.91-8.0(\mathrm{~m}, 4 \mathrm{H}), 8.12-8.14(\mathrm{~m}$, $1 \mathrm{H}), 8.23-8.26(\mathrm{~m}, 1 \mathrm{H}), 8.42\left(\mathrm{~d}, J^{3}=8.0 \mathrm{~Hz}, 1 \mathrm{H}\right), 9.20\left(\mathrm{~d}, J^{3}=\right.$ $8.0 \mathrm{~Hz}, 1 \mathrm{H})$.

3-Amino-1-(2-nitrophenyl)-1H-benzo[a]pyrano[2,3-c] phenazine-2-carbonitrile (6k). Brown solid, mp: $279-283{ }^{\circ} \mathrm{C}$; IR $\left(\mathrm{KBr}, \nu, \mathrm{cm}^{-1}\right): 3437,3063,2194,1664,1629,1594,1526,1388$, $1351 ;{ }^{1} \mathrm{H}$ NMR $\left(400 \mathrm{MHz}, \mathrm{DMSO}-d_{6}\right)(\delta, \mathrm{ppm}): 6.11(\mathrm{~s}, 1 \mathrm{H}), 7.31$ $\left(\mathrm{t}, J^{3}=8.0 \mathrm{~Hz}, 1 \mathrm{H}\right), 7.40\left(\mathrm{~d}, J^{3}=8.0 \mathrm{~Hz}, 1 \mathrm{H}\right), 7.47\left(\mathrm{t}, J^{3}=8.0 \mathrm{~Hz}\right.$, $1 \mathrm{H}), 7.52\left(\mathrm{~s}, \mathrm{NH}_{2}\right), 7.86-7.98(\mathrm{~m}, 4 \mathrm{H}), 8.19\left(\mathrm{~d}, J^{3}=8.0 \mathrm{~Hz}, 1 \mathrm{H}\right)$, $8.24-8.26(\mathrm{~m}, 1 \mathrm{H}), 8.28-8.31(\mathrm{~m}, 1 \mathrm{H}), 8.42\left(\mathrm{~d}, J^{3}=8.0 \mathrm{~Hz}, 1 \mathrm{H}\right)$, $9.13\left(\mathrm{~d}, J^{3}=8.0 \mathrm{~Hz}, 1 \mathrm{H}\right)$.

3-Amino-1-(4-nitrophenyl)-1H-benzo[a]pyrano[2,3-c] phenazine-2-carbonitrile (61). Yellow solid, mp: $277-280{ }^{\circ} \mathrm{C}$ (lit. 25: 281-283 $\left.{ }^{\circ} \mathrm{C}\right)$; IR (KBr, $\left.\nu, \mathrm{cm}^{-1}\right)$ : 3440, 3318, 3204, 3068, 2197, 1672, 1628, 1593, 1514, 1385, 1346; ${ }^{1} \mathrm{H}$ NMR (400 MHz, DMSO$\left.d_{6}\right)(\delta, \mathrm{ppm}): 5.61(\mathrm{~s}, 1 \mathrm{H}), 7.53-7.55\left(\mathrm{~m}, \mathrm{NH}_{2}\right), 7.67-7.71(\mathrm{~m}, 2 \mathrm{H})$, 7.93-8.01 (m, 4H), 8.08-8.12 (m, 2H), 8.25-8.29 (m, 2H), 8.44$8.46(\mathrm{~m}, 1 \mathrm{H}), 9.21-9.24(\mathrm{~m}, 1 \mathrm{H})$.

3-Amino-1-(3-methoxyphenyl)-1H-benzo[a]pyrano[2,3-c] phenazine-2-carbonitrile (6m). Yellow solid, mp: $238-243{ }^{\circ} \mathrm{C}$ (lit. 39: 240-242 ${ }^{\circ} \mathrm{C}$ ); IR (KBr, $\left.\nu, \mathrm{cm}^{-1}\right)$ : 3420, 3340, 3215, 2193, $1666,1596,1492,1385 ;{ }^{1} \mathrm{H}$ NMR $\left(400 \mathrm{MHz}\right.$, DMSO- $\left.d_{6}\right)(\delta, \mathrm{ppm})$ : $3.67(\mathrm{~s}, 3 \mathrm{H}), 5.48(\mathrm{~s}, 1 \mathrm{H}), 6.67\left(\mathrm{~d}, J^{3}=8.0 \mathrm{~Hz}, 1 \mathrm{H}\right), 6.91\left(\mathrm{~d}, J^{3}=\right.$ $8.0 \mathrm{~Hz}, 1 \mathrm{H}), 7.01(\mathrm{~s}, 1 \mathrm{H}), 7.13\left(\mathrm{t}, J^{3}=8.0 \mathrm{~Hz}, 1 \mathrm{H}\right), 7.40\left(\mathrm{~s}, \mathrm{NH}_{2}\right)$, $7.93-7.94(\mathrm{~m}, 2 \mathrm{H}), 7.99\left(\mathrm{t}, J^{3}=8.0 \mathrm{~Hz}, 2 \mathrm{H}\right), 8.15-8.18(\mathrm{~m}, 1 \mathrm{H})$, $8.25-8.28(\mathrm{~m}, 1 \mathrm{H}), 8.43\left(\mathrm{~d}, J^{3}=8.0 \mathrm{~Hz}, 1 \mathrm{H}\right), 9.21\left(\mathrm{~d}, J^{3}=8.0 \mathrm{~Hz}\right.$, $1 \mathrm{H})$.

3-Amino-1-(4-methoxyphenyl)-1H-benzo[a]pyrano[2,3-c] phenazine-2-carbonitrile (6n). Yellow solid, mp: $270-272{ }^{\circ} \mathrm{C}$; IR $\left(\mathrm{KBr}, \nu, \mathrm{cm}^{-1}\right): 3431,3314,3194,3047,2194,1667,1596,1508$, 1386; ${ }^{1} \mathrm{H}$ NMR (400 MHz, DMSO- $d_{6}$ ) $(\delta, \mathrm{ppm}): 3.61$ (s, 3H), 5.50 $(\mathrm{s}, 1 \mathrm{H}), 6.77\left(\mathrm{~d}, J^{3}=8.0 \mathrm{~Hz}, 2 \mathrm{H}\right), 7.19-7.21\left(\mathrm{~m}, \mathrm{NH}_{2}\right), 7.33\left(\mathrm{~d}, J^{3}=\right.$ $8.0 \mathrm{~Hz}, 2 \mathrm{H}), 7.95-8.0(\mathrm{~m}, 4 \mathrm{H}), 8.20-8.22(\mathrm{~m}, 1 \mathrm{H}), 8.30-8.31(\mathrm{~m}$, $1 \mathrm{H}), 8.46\left(\mathrm{~d}, J^{3}=8.0 \mathrm{~Hz}, 1 \mathrm{H}\right), 9.26\left(\mathrm{~d}, J^{3}=8.0 \mathrm{~Hz}, 1 \mathrm{H}\right)$.

3-Amino-1-(2,3-dimethoxyphenyl)-1H-benzo[a]pyrano[2,3-c] phenazine-2-carbonitrile (6o). Yellow solid, mp: $287-291{ }^{\circ} \mathrm{C}$ (lit. 25: 292-294 $\left.{ }^{\circ} \mathrm{C}\right)$; IR (KBr, $\left.\nu, \mathrm{cm}^{-1}\right)$ : 3426, 3312, 3174, 3051, 2187, $1659,1624,1592,1491,1387 ;{ }^{1} \mathrm{H}$ NMR $\left(400 \mathrm{MHz}, \mathrm{DMSO}-d_{6}\right)(\delta$, ppm): $3.84(\mathrm{~s}, 3 \mathrm{H}), 3.88(\mathrm{~s}, 3 \mathrm{H}), 5.83(\mathrm{~s}, 1 \mathrm{H}), 6.73\left(\mathrm{t}, J^{3}=8.0 \mathrm{~Hz}\right.$, $1 \mathrm{H}), 6.95\left(\mathrm{~d}, J^{3}=8.0 \mathrm{~Hz}, 1 \mathrm{H}\right), 7.05-7.11(\mathrm{~m}, 1 \mathrm{H}), 7.19\left(\mathrm{~s}, \mathrm{NH}_{2}\right)$, 7.89-8.02 (m, 5H), 8.25-8.27 (m, 1H), $8.46\left(\mathrm{~d}, J^{3}=8.0 \mathrm{~Hz}, 1 \mathrm{H}\right)$, $9.24\left(\mathrm{~d}, J^{3}=8.0 \mathrm{~Hz}, 1 \mathrm{H}\right)$.

3-Amino-1-(o-tolyl)-1H-benzo[a]pyrano[2,3-c]phenazine-2carbonitrile (6p). Yellow solid, mp: 256-260 ${ }^{\circ} \mathrm{C}$; IR $(\mathrm{KBr}$, $\left.\nu, \mathrm{cm}^{-1}\right)$ : 3486, 3309, 3174, 3061, 2194, 1662, 1627, 1595, 1386; ${ }^{1} \mathrm{H}$ NMR (400 MHz, DMSO- $\left.d_{6}\right)(\delta, \mathrm{ppm}): 2.18(\mathrm{~s}, 3 \mathrm{H}), 5.44(\mathrm{~s}, 1 \mathrm{H})$, $6.89\left(\mathrm{~d}, J^{3}=8.0 \mathrm{~Hz}, 1 \mathrm{H}\right), 7.10\left(\mathrm{t}, J^{3}=8.0 \mathrm{~Hz}, 1 \mathrm{H}\right), 7.19(\mathrm{~m}, 2 \mathrm{H})$, $7.36\left(\mathrm{~s}, \mathrm{NH}_{2}\right), 7.91-7.92(\mathrm{~m}, 2 \mathrm{H}), 7.97-8.0(\mathrm{~m}, 2 \mathrm{H}), 8.13-8.14(\mathrm{~m}$, $1 \mathrm{H}), 8.23-8.25(\mathrm{~m}, 1 \mathrm{H}), 8.43\left(\mathrm{~d}, J^{3}=8.0 \mathrm{~Hz}, 1 \mathrm{H}\right), 9.20\left(\mathrm{~d}, J^{3}=\right.$ $8.0 \mathrm{~Hz}, 1 \mathrm{H})$.

3-Amino-1-( $p$-tolyl)-1H-benzo[ $a]$ pyrano[2,3-c]phenazine-2carbonitrile (6q). Yellow solid, mp: 295-297 ${ }^{\circ} \mathrm{C}$ (lit. 25: 293-294 $\left.{ }^{\circ} \mathrm{C}\right)$; IR (KBr, $\nu, \mathrm{cm}^{-1}$ ): 3441, 3311, 3177, 3054, 2187, 1659, 1623, 1594, 1496, $1387 ;{ }^{1} \mathrm{H}$ NMR (400 MHz, DMSO- $\left.d_{6}\right)(\delta, \mathrm{ppm}): 2.13$ $(\mathrm{s}, 3 \mathrm{H}), 5.45(\mathrm{~s}, 1 \mathrm{H}), 7.01\left(\mathrm{~d}, J^{3}=8.0 \mathrm{~Hz}, 2 \mathrm{H}\right), 7.27\left(\mathrm{~d}, J^{3}=\right.$ $8.0 \mathrm{~Hz}, 2 \mathrm{H}), 7.34\left(\mathrm{~m}, \mathrm{NH}_{2}\right), 7.91-8.0(\mathrm{~m}, 4 \mathrm{H}), 8.14-8.16(\mathrm{~m}, 1 \mathrm{H})$, $8.25-8.27(\mathrm{~m}, 1 \mathrm{H}), 8.43\left(\mathrm{~d}, J^{3}=8.0 \mathrm{~Hz}, 1 \mathrm{H}\right), 9.22\left(\mathrm{~d}, J^{3}=8.0 \mathrm{~Hz}\right.$, $1 \mathrm{H})$.

\section{Conflicts of interest}

There are no conflicts to declare.

\section{Acknowledgements}

The authors are grateful to University of Kashan for supporting this work by Grant No. 159148/89.

\section{References}

1 S. Gilje, S. Han, M. Wang, K. L. Wang and R. B. Kaner, Nano Lett., 2007, 7, 3394-3398.

2 Y. Liang, H. Wang, H. S. Casalongue, Z. Chen and H. Dai, Nano Res., 2010, 3, 701-705.

3 S. Stankovich, D. A. Dikin, O. C. Compton, G. H. Dommett, R. S. Ruoff and S. T. Nguyen, Chem. Mater., 2010, 22, 41534157. 
4 Y. Xu, H. Bai, G. Lu, C. Li and G. Shi, J. Am. Chem. Soc., 2008, 130, 5856-5857.

5 G. Williams, B. Seger and P. V. Kamat, ACS Nano, 2008, 2, 1487-1491.

6 S. He, B. Song, D. Li, C. Zhu, W. Qi, Y. Wen, L. Wang, S. Song, H. Fang and C. Fan, Adv. Funct. Mater., 2010, 20, 453-459.

7 F. Schedin, A. Geim, S. Morozov, E. Hill, P. Blake, M. Katsnelson and K. Novoselov, Nat. Mater., 2007, 6, 652655.

8 M. Golestanzadeh, H. Naeimi and Z. Zahraie, Mater. Sci. Eng., C, 2017, 71, 709-717.

9 T. A. Pham, N. A. Kumar and Y. T. Jeong, Synth. Met., 2010, 160, 2028-2036.

10 A. Sunder, R. Mülhaupt, R. Haag and H. Frey, Adv. Mater., 2000, 12, 235-239.

11 Z. Chen, L. Zhou, F. Zhang, C. Yu and Z. Wei, Appl. Surf. Sci., 2012, 258, 5291-5298.

12 A. Hasaninejad and S. Firoozi, Mol. Diversity, 2013, 17, 499513.

13 S. B. Ferreira, F. de Carvalho da Silva, F. A. Bezerra, M. Lourenco, C. R. Kaiser, A. C. Pinto and V. F. Ferreira, Arch. Pharm., 2010, 343, 81-90.

14 L. Bonsignore, G. Loy, D. Secci and A. Calignano, Eur. J. Med. Chem., 1993, 28, 517-520.

15 J. B. Laursen and J. Nielsen, Chem. Rev., 2004, 104, 16631686.

16 S. A. Gamage, J. A. Spicer, G. W. Rewcastle, J. Milton, S. Sohal, W. Dangerfield, P. Mistry, N. Vicker, P. A. Charlton and W. A. Denny, J. Med. Chem., 2002, 45, 740-743.

17 J. M. Ligon, D. S. Hill, P. E. Hammer, N. R. Torkewitz, D. Hofmann, H. J. Kempf and K. H. v. Pée, Pest Manage. Sci., 2000, 56, 688-695.

18 M. Muller and T. C. Sorrell, Prostaglandins, 1995, 50, 301311.

19 J. M. Khurana, A. Chaudhary, A. Lumb and B. Nand, Green Chem., 2012, 14, 2321-2327.

20 D. Yu, M. Suzuki, L. Xie, S. L. Morris-Natschke and K. H. Lee, Med. Res. Rev., 2003, 23, 322-345.

21 F. Borges, F. Roleira, N. Milhazes, L. Santana and E. Uriarte, Curr. Med. Chem., 2005, 12, 887-916.
22 J. G. Tangmouo, A. L. Meli, J. Komguem, V. Kuete, F. N. Ngounou, D. Lontsi, V. P. Beng, M. I. Choudhary and B. L. Sondengam, Tetrahedron Lett., 2006, 47, 3067-3070.

23 A. S. Abd-El-Aziz, A. M. El-Agrody, A. H. Bedair, T. C. Corkery and A. Ata, Heterocycles, 2004, 63, 1793-1812.

24 R. O. S. Kitamura, P. Romoff, M. C. M. Young, M. J. Kato and J. H. G. Lago, Phytochemistry, 2006, 67, 2398-2402.

25 S.-L. Wang, F.-Y. Wu, C. Cheng, G. Zhang, Y.-P. Liu, B. Jiang, F. Shi and S.-J. Tu, ACS Comb. Sci., 2011, 13, 135-139.

26 H. R. Shaterian, F. Moradi and M. Mohammadnia, C. R. Chim., 2012, 15, 1055-1059.

27 H. R. Shaterian and M. Mohammadnia, J. Mol. Liq., 2013, 177, 162-166.

28 A. Yazdani-Elah-Abadi, M.-T. Maghsoodlou, R. Mohebat and R. Heydari, Chin. Chem. Lett., 2017, 28, 446-452.

29 N. Cai, C. Li, X. Luo, Y. Xue, L. Shen and F. Yu, J. Mater. Sci., 2016, 51, 797-808.

30 R. Kabiri and H. Namazi, J. Nanopart. Res., 2014, 16, 2474.

31 S. Stankovich, D. A. Dikin, R. D. Piner, K. A. Kohlhaas, A. Kleinhammes, Y. Jia, Y. Wu, S. T. Nguyen and R. S. Ruoff, Carbon, 2007, 45, 1558-1565.

32 S. H. Lee, D. R. Dreyer, J. An, A. Velamakanni, R. D. Piner, S. Park, Y. Zhu, S. O. Kim, C. W. Bielawski and R. S. Ruoff, Macromol. Rapid Commun., 2010, 31, 281-288.

33 M. Gkikas, G. V. Theodosopoulos, B. P. Das, M. Tsianou, H. Iatrou and G. Sakellariou, Eur. Polym. J., 2014, 60, 106113.

34 A. Esfandiar, O. Akhavan and A. Irajizad, J. Mater. Chem., 2011, 21, 10907-10914.

35 H. R. Shaterian, F. Moradi and M. Mohammadnia, C. $R$. Chim., 2012, 15, 1055-1059.

36 A. Yazdani-Elah-Abadi, R. Mohebat and M.-T. Maghsoodlou, RSC Adv., 2016, 6, 84326-84333.

37 A. Landarani-Isfahani, A. Taheri-Kafrani, M. Amini, V. Mirkhani, M. Moghadam, A. Soozanipour and A. Razmjou, Langmuir, 2015, 31, 9219-9227.

38 A. R. Kiasat, A. Mouradzadegun and S. J. Saghanezhad, Res. Chem. Intermed., 2015, 41, 319-326.

39 A. Y. E. Abadi, M.-T. Maghsoodlou, R. Heydari and R. Mohebat, Res. Chem. Intermed., 2016, 42, 1227-1235. 